\title{
Medication use by the elderly: analysis of prescribing, dispensing, and use in a medium-sized city in the state of São Paulo
}

\author{
Isabel Cristina Aparecida Stefano' \\ Lucieni Oliveira Conterno ${ }^{2}$ \\ Carlos Rodrigues da Silva Filho² \\ Maria José Sanches Marin ${ }^{3}$
}

\section{Abstract}

Objective: To describe the prescribing, dispensing, use, adhesion, and storage of medicines to and by the elderly. Method: A descriptive cross-sectional study was performed in Estratégia Saúde da Família (Family Health Strategy) health centers (ESF), in Marília in the state of São Paulo, Brazil, based on the records of and interviews with 114 individuals seven to ten days after a medical consultation. A descriptive analysis was carried out. Results: The mean number of prescribed drugs was 4.98 per elderly patient. Of the total number of prescribed drugs, $81.5 \%$ were supplied by public services, with the nutrient (50\%); antilipemic (62.1\%); analgesic (30.7\%); dermo-protector $(66.6 \%)$; herbal $(40 \%)$ and parasite and antifungal (37.5\%) classes dispensed the least. A total of $83.8 \%$ of the prescribed drugs were used, while the drugs dispensed at the lowest rates were not used by the elderly, except for analgesics. A total of $40.3 \%$ of the respondents exhibited low adherence. Most stored their medicines in a suitable place. Conclusion: The prescribing, dispensing, use and storage of medications to and by the elderly can be considered effective, but adherence remains low, requiring new strategies and interventions.

\footnotetext{
Secretaria da Saúde do Estado de São Paulo, Departamento Regional de Saúde (DRS-IX). Marília, SP, Brasil

2 Faculdade de Medicina de Marília, Curso de Medicina. Marilia, SP, Brasil.

3 Faculdade de Medicina de Marília, Curso de Enfermagem. Marilia, SP, Brasil.

Keywords: Elderly. Drug Utilization. Drug Prescriptions Family Health Strategy. 


\section{INTRODUCTION}

The use of medication is a frequent occurrence among the elderly, and while it contributes to prolonging and improving life, it can also generate serious health problems, especially when it is inadequate, either due to the prescription, dispensation or taking of the drugs ${ }^{1}$. The indiscriminate use of medicines has a clinical and economic impact, and is considered a key indicator of patient safety ${ }^{2}$.

In Brazil, approximately $80 \%$ of elderly persons living in the community use at least one type of medication ${ }^{2,3}$. The use of more than one drug is also a common practice among this group, and may lead to complications arising from adverse reactions ${ }^{4}$.

The World Health Organization (WHO) considers that more than $50 \%$ of drugs are prescribed or dispensed inadequately and that $50 \%$ of patients use medicines incorrectly. The most common targets of inadequate drug use are individuals who use polypharmacy, the inappropriate use of antibiotics and injectable drugs, self-medication, and prescription that disagrees with best practices ${ }^{5}$. There are also shortcomings in the selection, supply and quality control processes and a lack of treatment guidance, which results in low adherence, misuse and ineffective treatment ${ }^{5}$.

Policies have been proposed aimed at achieving more adequate medication use in Brazil. At the national level, the National Medication Policy ${ }^{6}$ is the main instrument for guiding health actions related to the use of drugs. Its main objective is to guarantee the safety, efficacy and quality of medicines, to promote their rational use and to ensure the access of the population to those drugs that are considered essential. Among the priorities are the promotion of the rational use of medicines, which includes appropriate prescription, timely availability and affordable prices; adequate dispensing and the consumption of effective, safe and high-quality medicinal products at the recommended doses at defined intervals and within the suggested period of time ${ }^{6}$.

Another important aspect to consider is the timing of dispensation. Law No. 5991, dated
December 17, 1973, which regulates the "sanitary control of the commercialization of drugs, medicines, pharmaceutical supplies and related products" in Brazil, adopts the following guidelines for dispensing: "the supply of drugs, pharmaceuticals, pharmaceutical supplies and related items, whether remunerated or otherwise"7.

In the context of the adequate use of medication, adherence is an even more complex condition, as it is a multifactorial process, encompassing physical, psychological, social, cultural, economic and behavioral aspects that require shared decisions and co-responsibility between the sick person, the health team and the social network ${ }^{8}$.

The present study aims to characterize and describe the practice of prescribing, dispensing, using, adhering to and storing medications by elderly users of the Estratégia Saúde da Família (the Family Health Strategy) (ESF) in the city of Marília, a city in the state of São Paulo, with the aim of supporting policies and actions that encourage their proper use.

\section{METHODS}

A descriptive and cross-sectional study was carried out in ESF units in a city located in the central-west of the state of São Paulo, with a population of approximately 220,000 inhabitants. Of these, 28,600 are elderly, representing $13 \%$ of the total population (Instituto Brasileiro de Geografia e Estatística Brazilian) (Institute of Geography and Statistics) (IBGE)?

The basic health care network of the city is composed of 12 Unidades Básicas de Saúde (Basic Health Units) (UBS) and 34 Family Health Strategy (ESF) units, which are the gateway to the health system. The ESF units serve approximately 54\% of the total population of the city. The supply of medicines in each of the Basic Health Units occurs through a monthly request which falls under the responsibility of the nursing team.

In addition, the city also has a Unidade Central da Assistência Farmacêutica (Central Pharmaceutical Assistance Unit) (UCAF), which meets requirements 
derived mainly from hospital and outpatient care units, as well as from long-term care institutions. It is important to note that standardized and available drugs are provided, where the prescription uses the generic name, in accordance with current legislation. The city also has two Farmácia Popular do Brasil (Brazil Popular Pharmacy) units, a federal government program that provides medicines at cost price via prescriptions. In 2005, the Farmácia Municipal de Manipulação (Municipal Compounding Pharmacy) (Fitosaúde) was established, which dispenses medicines for the prescriptions of patients receiving care through the Sistema Único de Saúde (Unified Health System) (SUS) of the city of Marília and, in 2009, the Farmácia de Medicamentos Excepcionais (Exceptional Medicines Pharmacy) (Medex) of the Marília Health Region was created, which provides rare and costly drugs for some specific pathologies ${ }^{10}$.

For data collection, two ESF units from each region of the city (north, south, east and west) were drawn, giving a total of eight. For the sample calculation, the estimated population of elderly people included in the ESF was considered. Among the 28,600 elderly persons, the prevalence of medication use was $80 \%$, with a margin of error of $10 \%$ and a confidence level of $99 \%$. A value of $10 \%$ was added to the total to cover possible losses or refusals, resulting in a sample of 114 elderly persons.

A total of 30 elderly people from the eastern region, 25 from the southern region, 33 from the north region and 26 from the western region were interviewed, considering the proportion of the population by area of coverage, giving a total of 114 elderly people. Included in the study were elderly people who could communicate clearly or who were accompanied by a caregiver, while those who were not at home on three visits or who could not communicate clearly and were alone at home at the time of the visit were excluded. The study was carried out from July to December 2013 and was supported by Community Health Agents who took the researcher to the homes and introduced the same to the elderly persons and their relatives.

Data collection was performed by one of the authors. Initially, medical records were consulted to obtain information about the prescribed drugs and the address of the elderly, soon after they had attended a medical consultation. Seven to ten days after the medical consultation, home visits were carried out and all those who agreed to participate in the study were interviewed using a previously prepared instrument. When the elderly person was unable to provide the information, it was supplied by the caregiver or family members.

Sociodemographic and epidemiological data were collected, such as skin color/ethnicity, schooling, occupation, family income, health plan, reported diseases, hospitalization in the previous year, and the economic status of each elderly person using the Brazilian economic classification scale. In order to evaluate social class, the Critério de Classificação Econômica Brasil (Brazilian Economic Classification Criterion) (CCEB) was applied, divided into six classes (A1, A2, B1, B2, C and D) ${ }^{11}$. In addition, the following items were verified: the form of acquisition of the medicines prescribed at the last consultation (whether through purchase in private pharmacies or through dispensing via public and/or private services); which medications prescribed at the last visit were currently being used; if other continuous use drugs had been prescribed, and also adherence to regular medications.

In order to verify adherence, a question was asked about the correct use of medication, as proposed by Haynes et al.: Most people have trouble taking pills, in the last 30 days have you had some difficulty taking yours? If the answer is affirmative it indicates that the individual is non-adherent ${ }^{12,13}$. To identify the degree of adherence to drug treatment, the Morisky test was employed, which is widely used by Brazilian studies in this area due to its reliability.

In this test, the patient is classified as belonging to the high degree of adherence group when all the answers are negative, while when at least one of the answers is affirmative, the patient is classified as belonging to the low adherence group. The Morisky test also allows us to discriminate whether low-adherence behavior is unintentional or intentional ${ }^{12,13}$.

Another evaluated item was the form and storage conditions of the medications, at which point the 
participant was asked to show where the medicines were stored.

The drugs were classified according to the Anatomical Therapeutic Chemical (ATC) Classification System ${ }^{14}$, with information about the class and the active principle according to the anatomical group or system in which it acts also included. A descriptive analysis of the data was carried out.

To comply with the ethical concepts of research involving human beings, the present study received the authorization of the Municipal Health Department and was approved by the Ethics Committee on Research involving Human Beings of the Faculdade de Medicina de Marília (Marília Medicine School), under Opinion N $N^{\circ} 303.105$ dated $13 / 06 / 2013$. The participants were advised of the procedures of the study and when in agreement signed a Free and Informed Consent Form.

\section{RESULTS}

A total of 114 elderly people participated in the study. In terms of the main demographic characteristics, $62.3 \%(\mathrm{n}=71)$ were women, $53.5 \%$ $(\mathrm{n}=61)$ were aged $60-69$ years, $92.1 \%(\mathrm{n}=105)$ had little or no schooling; $78.9 \%(\mathrm{n}=90)$ were retired or pensioners; $14.9 \%(\mathrm{n}=17)$ lived alone; $98.2 \%(\mathrm{n}=102)$ belonged to social classes D and C; and 6.1\% ( $\mathrm{n}=7$ ) had a Private Health Plan (Table 1).

Table 2 shows the diseases reported by the elderly persons interviewed, grouped according to the ICD 10. Of the interviewees, $85.0 \%(\mathrm{n}=97)$ reported diseases of the Cardiovascular System, with SAH the most frequently mentioned. Endocrine, nutritional and metabolic diseases were reported by $46.5 \%(\mathrm{n}=53)$ of the elderly, with a predominance of Diabetes Mellitus; followed by infectious and osteoarticular diseases, mainly chronic pain. The average was two diseases described per elderly person.

Table 1. Sociodemographic variables of 114 elderly persons resident in the area covered by the eight family health units. Marília, São Paulo, 2014.

\begin{tabular}{lc}
\hline Age (years) & Number $(\%)$ \\
\hline $60-69$ & $61(53.5)$ \\
$70-79$ & $39(34.2)$ \\
$\geq 80$ & $14(12.3)$ \\
\hline Gender & \\
Female & $71(62.3)$ \\
Male & $43(37.7)$ \\
Marital Status & \\
Lives alone (single, widowed, separated, divorced) & $58(50.9)$ \\
Married/common-law-marriage & $56(49.1)$ \\
\hline Schooling (years) & \\
None & $39(34.2)$ \\
$\leq 4$ & $66(57.9)$ \\
+4 & $09(07.9)$ \\
B2 & $02(01.8)$ \\
C & $50(45.0)$ \\
D & $59(53.2)$ \\
\hline Health Plan & \\
No & $107(93.9)$ \\
Yes & $07(06.1)$ \\
\hline
\end{tabular}


Table 2. Diseases described by 114 elderly persons interviewed based on International Classification of Diseases (ICD-10). Marília, São Paulo, 2014.

\begin{tabular}{|c|c|}
\hline Diseases reported & Number $(\%)$ \\
\hline Cardiovascular disease & $97(85.0)$ \\
\hline Systemic Arterial Hypertension & $79(69.3)$ \\
\hline Cardiac insufficiency & $2(01.7)$ \\
\hline Coronary insufficiency & $4(03.5)$ \\
\hline Others & $5(04.4)$ \\
\hline Heart Arrhythmia & $7(06.1)$ \\
\hline Endocrinopathy & $53(46.5)$ \\
\hline Type 2 Diabetes Mellitus & $35(30.7)$ \\
\hline Hypothyroidism & $9(07.9)$ \\
\hline Dyslipidemia & $9(07.9)$ \\
\hline Osteoarticular & $19(16.7)$ \\
\hline Osteoarthrosis & $7(06.1)$ \\
\hline Chronic Pain & $12(10.6)$ \\
\hline Intestinal Gastrointestinal Tract & $3(02.6)$ \\
\hline Gastritis & $2(01.7)$ \\
\hline Cholecystitis & $1(00.9)$ \\
\hline Central Nervous System & $7(06.1)$ \\
\hline Headache, Dementia, Stroke Sequela & $4(03.5)$ \\
\hline Epilepsy & $3(02.6)$ \\
\hline Psychiatric & $5(04.4)$ \\
\hline Depression & $5(04.4)$ \\
\hline Genito-Urinary & $9(07.8)$ \\
\hline Urinary Incontinence, Urinary Tract Infection & $6(05.2)$ \\
\hline Pelvic Inflammatory Disease & $3(02.6)$ \\
\hline Respiratory Tract & $6(05.2)$ \\
\hline Chronic bronchitis & $2(01.7)$ \\
\hline Asthma & $1(00.9)$ \\
\hline Emphysema & $3(02.6)$ \\
\hline Infectious diseases & $17(14.9)$ \\
\hline Respiratory Tract (Cold / Flu) & $16(14.0)$ \\
\hline Pneumonia & $1(00.9)$ \\
\hline Hematologic System & $5(04.4)$ \\
\hline Anemia & $5(04.4)$ \\
\hline Other (Chronic Ulcers, Pressure Ulcers) & $3(02.6)$ \\
\hline Total & $224(100)^{*}$ \\
\hline
\end{tabular}

*Some of the 114 elderly persons described more than one disease.

According to the medical records of the 114 elderly people who had attended a medical consultation, 568 medications were prescribed, with an average of 4.98 medications per elderly person. The most prescribed drugs were those of the Cardiovascular Apparatus
$(38 \%)(\mathrm{n}=216)$, followed by drugs that work in the Digestive System $(10.9 \%)(\mathrm{n}=62)$, especially antacids; and those of the Endocrine $(10.6 \%)(\mathrm{n}=60)$ and the Central Nervous Systems (10.2\%) ( $\mathrm{n}=58)$, mainly antidepressants (Table 3). 
Table 3. Classes of Medications prescribed and dispensed in the Health Unit and used by patients. Marília, São Paulo, 2014.

\begin{tabular}{|c|c|c|c|c|c|}
\hline & Prescribed & Dispensed & $\% *$ & Used & $\% * *$ \\
\hline Central Nervous System & 58 & 54 & 93.1 & 54 & 93.1 \\
\hline Antidepressants (Fluoxetine, Amitriptyline) & 29 & 26 & 89.6 & 26 & 89.6 \\
\hline $\begin{array}{l}\text { Anxiolytics and Hypnotics } \\
\text { (Diazepam, nitrazepam, clonazepam) }\end{array}$ & 16 & 16 & 100 & 16 & 100 \\
\hline $\begin{array}{l}\text { Antipsychotics, Neuropiletics and } \\
\text { Anti-Parkinson (chlorpromazine, Clonazepam, } \\
\text { Benzerazide, Lithium Carbonate) }\end{array}$ & 8 & 8 & 100 & 8 & 100 \\
\hline Anticonvulsants (Phenobarbital) & 5 & 4 & 80.0 & 4 & 80.6 \\
\hline Cardiovascular system & 216 & 172 & 79.6 & 179 & 82.8 \\
\hline $\begin{array}{l}\text { Antihypertensives (Atenolol, Propranolol, } \\
\text { Enalapril, Losartan) }\end{array}$ & 127 & 115 & 90.5 & 115 & 90.5 \\
\hline Antiplatelet Agents and Antithrombotics (ASA) & 43 & 42 & 97.6 & 42 & 97.6 \\
\hline 5Antilipemic (Simvastatin, Ciprofibrate) & 37 & 14 & 37.8 & 14 & 37.8 \\
\hline $\begin{array}{l}\text { Other (Flunarizine, Warfarin, Diosmin, } \\
\text { Mon. Isosorbide) }\end{array}$ & 9 & 1 & 11.1 & 8 & 88.8 \\
\hline Urinary system & 52 & 49 & 94.2 & 45 & 86.5 \\
\hline $\begin{array}{l}\text { Loop and Thiazide Diuretics (Furosemide, } \\
\text { Hydrochlorothiazide, Spironolactone) }\end{array}$ & 52 & 49 & 94.2 & 45 & 86.5 \\
\hline Digestive System & 60 & 43 & 71.6 & 43 & 71.6 \\
\hline Antacid and Inhib. Gastric Sections (Omeprazole) & 31 & 29 & 93.5 & 29 & 93.5 \\
\hline Nutrients (Ferrous Sulfate, Complex B) & 20 & 10 & 50.0 & 10 & 50.0 \\
\hline $\begin{array}{l}\text { Others (Buscopan, mineral oil, } \\
\text { Saccharomyces Boulardil) }\end{array}$ & 9 & 4 & 44.4 & 4 & 44.4 \\
\hline Muscular and Skeletal System & 30 & 25 & 83.3 & 29 & 96.7 \\
\hline Non-steroidal Anti-inflammatory, Steroid & 15 & 14 & 93.3 & 14 & 93.3 \\
\hline Non-Opoid Analgesics, antipyretics & 13 & 9 & 69.2 & 13 & 100 \\
\hline Sodium alendronate) & 2 & 2 & 100 & 2 & 100 \\
\hline Respiratory system & 23 & 23 & 100 & 23 & 100 \\
\hline $\begin{array}{l}\text { Bronchodilators and antiasthmatics (aminophylline, } \\
\text { bamiphyline, formoterol fumarate, budenosine) }\end{array}$ & 18 & 18 & 100 & 18 & 100 \\
\hline Expectorant (Carbocysteine) & 5 & 5 & 100 & 5 & 100 \\
\hline Endocrine system & 60 & 56 & 93.3 & 57 & 95.0 \\
\hline $\begin{array}{l}\text { Insulin and Other Diabetic Agents } \\
\text { (Metformin, NPH Insulin) }\end{array}$ & 48 & 44 & 91.7 & 45 & 93.8 \\
\hline Thyroid Hormone (Levothyroxine) & 12 & 12 & 100 & 12 & 100 \\
\hline Herbal Medicines or Medicinal Herbs & 25 & 15 & 60 & 18 & 72.0 \\
\hline Dermoprotector & 9 & 3 & 33.3 & 9 & 100 \\
\hline Antiparasitics and Antifungals & 8 & 5 & 62.5 & 6 & 75.0 \\
\hline $\begin{array}{l}\text { Antimycotics and Antifungals } \\
\text { (Ketoconazole, Fluconazole) }\end{array}$ & 8 & 5 & 62.5 & 6 & 75.0 \\
\hline Antimicrobials (Amoxilin, Cyprofloxaxin, etc.) & 14 & 11 & 78.6 & 11 & 78.6 \\
\hline Other (Antihypertensive, Anti Glaucomatous) & 13 & 7 & 53.8 & 2 & 15.4 \\
\hline Total & 568 & 463 & 81.5 & 476 & 83.8 \\
\hline
\end{tabular}

* Percentage of times the medication was prescribed; ** Percentage of the time the prescribed medication was used by the patient. 
Of the drugs prescribed by the ESF, $75.5 \%$ $(n=429)$ were dispensed by the unit itself, $4.4 \%$ $(\mathrm{n}=25)$, by Medex and $1.58 \%(\mathrm{n}=9)$ were acquired from the Farmácia Popular, meaning that $81.5 \%$ of the medicines were dispensed by the public service.

Among the drugs prescribed, it is worth noting some classes were dispensed in smaller quantities by public health services, mainly nutrients (50\%); antilipemics (62.1\%); analgesics (30.8\%); dermoprotectors (66.6\%); phytotherapics $(40 \%)$ and antiparasitics and antifungals $(37.5 \%)$.

Among the drugs prescribed, some classes were used less, such as antilipemics (62.1\%), nutrients $(50 \%)$, herbal remedies or medicinal herbs $(28 \%)$, antimycotics and antifungal drugs (25\%) and antimicrobials (21.4\%). Analgesics, even when not dispensed by public health services, were used by almost all the elderly.

Table 4 shows the Degree of Adherence to the treatment. Of the interviewees, $59.6 \%(\mathrm{n}=68)$, were classified as adherent. The other $40.3 \%(n=46)$ presented moderate to low adherence, of which $22.8 \%(\mathrm{n}=26)$ were classified as intentionally nonadherent, while in $6.14 \%(\mathrm{n}=7)$ the low adherence was characterized as unintentional. Of the elderly persons interviewed, $11.4 \%(\mathrm{n}=13)$ presented both types of behavior. Moderate or low adherence was also verified in $28.9 \%(\mathrm{n}=33)$ and $11.4 \%(\mathrm{n}=13)$ of the elderly, respectively.

In terms of the storage of the medications, 655 drugs were found in the homes of the elderly, representing those that were prescribed at the last medical consultation and other non-prescribed drugs in use.

According to Table 5, the majority of the elderly, $68.4 \%(n=448)$, stored their medications in the kitchen cabinet or drawer. Medicines exposed to sunlight, humidity or excessive heat were not found. It was noted, however, that $9.6 \%$ of the patients ( $n=11)$ kept their medications without their packaging (blister pack or box), making it difficult to identify them at the time of use.

Table 4. Degree of Adherence of patients according to Morisky Green Test. Marília, São Paulo, 2014.

\begin{tabular}{ll}
\hline Degree of Adherence (positive response) & Number $(\%)$ \\
\hline Adherent (none) & $68(59.6)$ \\
Moderate adhesion (1 or 2) & $33(28.9)$ \\
Low adhesion (3 to 4) & $13(11.4)$ \\
Total & $114(100)$ \\
\hline
\end{tabular}

Table 5. Storage location of medications used by patients. Marília, São Paulo, 2014.

\begin{tabular}{ll}
\hline Storage location & Number $(\%)$ \\
\hline Kitchen Cabinet or Drawer & $448(68.4)$ \\
Bedroom Cabinet or Drawer & $134(20.4)$ \\
Bathroom Cabinet or Drawer & $37(5.6)$ \\
Next to Water Filter & $12(1.8)$ \\
On top of refrigerator & $5(0.7)$ \\
Other & $19(2.9)$ \\
Total & $655(100)$ \\
\hline
\end{tabular}




\section{DISCUSSION}

The present study evaluates the prescription, dispensing and use of medications by 114 elderly people. These individuals were mostly female, lived without a partner, had a low level of schooling and lived off their pensions, as other studies of the elderly population have shown ${ }^{15}$.

In terms of reported medical diagnosis, diseases of the Cardiovascular System (Hypertension), the Endocrine System (Type 2 Diabetes Mellitus and Hypothyroidism) and Infectious (Cold/Flu) and Osteoarticular diseases (chronic joint pain) were the most prevalent, data that reinforces the findings of other studies ${ }^{16,17}$. These conditions require constant monitoring by health teams and proper monitoring and control, as well as the regular dispensing of medications.

A finding of polypharmacy was expected for this segment of the population. The explanation for this condition is multifactorial, as it is mainly influenced by the accumulation of multiple chronic diseases and clinical manifestations resulting from aging, as well as a lack of preparation among health professionals to provide rational pharmacological interventions for patients who require them. A more thorough and systematic approach is therefore needed for elderly persons who genuinely require drug interventions ${ }^{18}$.

The groups of medications most used by the elderly were those that relate to the Cardiovascular and Endocrine Systems and which work in the Central Nervous, Urinary and Digestive systems. These results corroborate the morbidity profile found and the results obtained in the study carried out in Goiânia (Goias) ${ }^{16}$. They are also linear to the prevalence and accumulation of pathologies of these systems which, in this age group, often require pharmacological interventions for their control. Compensatory pharmacological intervention occurs in the digestive system in order to correct dysfunctions or to protect the system against aggressions derived from polymedication ${ }^{19,20}$.

Such diseases clearly require constant investment in strategies that promote health, support their control and the prevention of complications, and focus on maintaining independence, so preventing and delaying potential illnesses and disabilities, as well as in the timely provision of treatment ${ }^{16}$.-

When analyzing adherence to drug treatment, it was found that $22.8 \%$ exhibited non-adhesive behavior, numbers slightly greater than a study carried out in Belo Horizonte (Minas Gerais), where non-adherents represented $22.5 \%$ of the sample ${ }^{21}$.

In the evaluation of degree of adherence to treatment, it was observed that $40.3 \%$ of the patients presented low adherence, a result consistent with that of several studies in Brazil and other developed countries $^{22}$. The percentage of drug treatment adherence ranged from $26.7 \%$ in Teresina (Piaui) ${ }^{23}$ to $43.3 \%$ in Santa Catarina (Santa Catarina) ${ }^{24}$.

Adherence problems are found in all situations where there is self-administration of treatment, regardless of the type of disease or the quality of and/or accessibility to health resources. The belief that patients are solely responsible for adherence is a misconception as several factors affect their behavior and adherence. These include social, economic and cultural factors and those related to the functioning of services, health professionals, basic diseases, comorbidities; treatment and, finally, the behavior of the patients themselves ${ }^{25}$.

In the present study, forgetfulness and the delayed taking of medications were described as the main causes for non-adherence to correct treatment. These are involuntary and unintentional behaviors and are similar to the problems related to non-adherence to treatment described in other Brazilian cities. They can potentially be improved by staff education and guidance strategies, in comparison with intentional non-compliance attitudes ${ }^{24,25}$.

Another variable associated with adherence is the patient's access to drug treatment. For the majority the drugs they did not use were those that were not dispensed, except for analgesics, which, even when not provided were used regularly. The results of another study carried out in the southern and northeastern regions of Brazil revealed inequity in health as a relevant factor, reinforcing the need for policies to increase access for poor and disadvantaged populations ${ }^{26}$. 
In the present study, $81.5 \%$ of the prescribed drugs were dispensed by public services, $83.8 \%$ of which were used by the elderly. A similar result was found in the municipality of Florianopolis (Santa Catarina $)^{27}$. This result is also in line with the WHO reference value, which considers access to medicines above $80 \%$ desirable $^{28}$.

The common causes for the difficulty of access of the elderly to medication refer to the ignorance of where and how to acquire such drugs and the difficulty of movement of the elderly population. Approximately 25\% of the medicines were not dispensed by the health unit where the elderly individuals had their medical consultation and of these, only $6 \%$ were acquired in other public services, which suggests that this population may have encountered difficulty accessing their medication, even when available in another public service. Although this condition was not the subject of the present study, the fact that waiting times and the location for the delivery of medicines, especially of exceptional medicines, may have caused suffering for those who need them and can lead to the abandonment of treatment ${ }^{29}$. It should be noted that a large percentage of the prescription drugs are included in the REMUME list, which should be a motivation for administrators to ensure their supply on a regular basis, as well as making them available in a location that is easily accessible to the elderly.

Despite this, it was noted that the majority of the drugs of continuous use such as antihypertensives and antidiabetics were dispensed to approximately $90 \%$ of the elderly.

A study that also analyzed the access of the population to drugs prescribed by public services, based on the 2008 Household Sample Survey, found that only $45.3 \%$ were dispensed ${ }^{30}$.

Given the expansion of this age group, the complexity of the management of Pharmaceutical Care in Brazil has grown, as the budget provided for the acquisition of drugs prescribed in the SUS tends to become increasingly significant and costly.

It was found that anti-lipemic drugs were not dispensed and were not being used by $62.1 \%$ of the elderly persons to whom they were prescribed.
This data should be of concern, since a study that accompanied elderly patients with dyslipidemia treated with drug therapy and dietary control for one year found a clinically relevant reduction in lipid levels. Failure to control these levels increases cardiovascular risks ${ }^{31}$.

The low use of antilipemics suggests the existence of a management problem, since, for the most part, these medications are included in the list of high cost drugs distributed by Medex.

In terms of nutrients, it was found that these were not widely dispensed or used. It is important to consider that, in the presence of nutritional changes, the actions of some medications may be modified. The deficiency of proteins and micronutrients, for example, can lead to the production of alkaline urine and the reabsorption of alkaline compounds, prolonging their half-life in the body ${ }^{32}$.

In contrast, the present study found that the elderly used the analgesics prescribed, even though most of them were not dispensed. The prescribing of analgesics, as it occurs where conditions and quality of life are significantly affected, may lead the elderly to acquire such drugs themselves. The occurrence of pain and the use of analgesics has increased in recent decades due to the prolonged life of individuals and the reduced tolerance to pain and suffering that is often observed ${ }^{33}$.

It should be emphasized that the prescription of analgesics is appropriate conduct on the part of the prescribing health professional, as the prolonged use of non-hormonal anti-inflammatory drugs or hormones by the elderly to control chronic pain would be inappropriate, except under very particular conditions and when closely controlled, considering the significant metabolic, hemodynamic and gastrointestinal complications that result from such interventions ${ }^{34}$. As for the use of herbal remedies and medicinal herbs that were dispensed to a lesser extent by the public services, it was found that these were not used by the elderly.

Regarding suitable storage locations for the medicines, it was observed that the great majority of the elderly population kept the medicines away from the light or excessive heat, usually in the kitchen, 
facilitating access and serving as a reminder to take them. However, the fact that some elderly persons keep their medicines without their packaging makes their recognition and proper use difficult, potentially leading to medication swapping and over-dosage. The absence of primary packaging was found in most of the households visited. The average number of drugs stored was 7.3 per household and the most common classes were antihypertensive, oral hypoglycemic agents and diuretics ${ }^{35}$.

The present study has many limitations due to its descriptive nature. The objective of the study was not the identification of the clinical aspects of the patients or the morbidities and comorbidities associated with drug intervention. Nevertheless, the prevalence of the morbidities identified was similar to those found in other recent Brazilian publications, which corroborates its external validity, or in other words, the patients studied have characteristics very similar to the average for the Brazilian population in this age group. In addition, it is not common to concomitantly and simultaneously evaluate aspects related to pharmacological intervention in the elderly, such as the prescription, dispensing, use and storage of the drugs recommended to them, which is one of the contributions of this study.

\section{CONCLUSIONS}

The classes of drugs available in the municipality account for $81.5 \%$ of the required drugs prescribed for the elderly. It is undeniable that the availability of free drugs, offered by the municipal, state and federal governments, has facilitated access to the prescribed drug treatment, which may mean greater control of diseases. The prescription, use and adequate home storage of medications, despite some problems being observed, gives the elderly a new opportunity to control acute and mainly chronic diseases, contributing to their longevity.

Adherence to therapy, a complex and multifactorial problem, also faces difficulties similar to those identified in other national and international studies.

The results obtained in the present study reveal a local health system that works, at least in terms of the prescription, dispensation and use of medication, in a concatenated, consecutive and consequential manner, with surprisingly little discontinuity, given the disparities of access and complexity of the population in relation to health care.

However, the fact that approximately $20 \%$ of medicines were not dispensed by public services indicates that these obstacles should be evaluated and overcome in order to facilitate access. The results also reveal the need for organization of the flow of medication distribution and/or the inclusion of new drugs, such as antilipemics and nutrients, facilitating access to such medications and helping to better control the diseases for which they are risk factors.

The importance of an organized system within an interconnected and integrated network of pharmaceutical care, with established guidelines, flows, routines and protocols, that aims to facilitate the access and movement of elderly persons to medication, reducing costs and providing greater quality in the care of this population, cannot be understated.

\section{REFERENCES}

1. Carvalho MFC, Romano-Lieber NSR, Mendes GB, Secoli SR, Ribeiro E, Lebrão ML, et al. Polifarmácia entre idosos do Município de São Paulo: Estudo SABE. Rev Bras Epidemiol. 2012;15(4):817-27.

2. Santi LQ. Prescrição: o que levar em conta? [Internet]. Brasília, DF: OPAS; 2016 [acesso em 29 ago 2017]. (Uso racional de medicamentos: fundamentação em condutas terapêuticas e nos processos da assistência farmacêutica; vol. 1, no. 14). Disponível em: http:// www.paho.org/bra/index.php?option=com_ docman\&view $=$ download\&category_slug $=$ serie-usoracional-medicamentos-284\&alias $=1542$-prescricaoo-que-levar-em-conta-2\&Itemid $=965$.

3. Gauterio DP, Santos SSC, Strapasson CMS, Vidal DAS, Piexak DR. Uso de medicamentos por pessoas idosas na comunidade: proposta de ação de enfermagem. Rev Bras Enferm. 2013;66(5):702-8. 
4. Oliveira LPBA, Santos SMA. An integrative review of drug utilization by the elderly in primary health care. Rev Esc Enferm USP. 2016;50(1):163-74.

5. World Health Organization. The safety of medicines in public health programmes: pharmacovigilance an essential tool. Geneva: WHO; 2006.

6. Brasil. Portaria n ${ }^{\circ} 3.916$, de 30 de outubro de 1998. Aprova a Política Nacional de Medicamentos. Diário Oficial da União. 10 nov. 1998;Seção 1:18-22.

7. Brasil. Lei no 5.991, de 17 de dezembro de 1973. Dispõe sobre o controle sanitário do comércio de drogas, medicamentos, insumos farmacêuticos e correlatos, e dá outras providências. Diário Oficial da União. 19 dez 1973;Seção 1:13049.

8. Remondi FA, Oda S, Cabrera MAS. Não adesão à terapia medicamentosa: da teoria a prática clínica. Rev Ciênc Farm Básica Apl. 2014;35(2):177-85.

9. Secretaria Municipal de Saúde de Marília. Programa Municipal de Saúde Mental. Marília: Prefeitura Municipal de Marília; 2013.

10. Instituto Brasileiro de Geografia e Estatística. População. Rio de Janeiro: IBGE; 2012.

11. Associação Brasileira de Empresas de Pesquisa. Critério de Classificação Econômica Brasil. Alterações na aplicação do Critério Brasil, válidas a partir de 01/01/2013 [Internet]. São Paulo: ABEP; 2012 [acesso em 23 fev. 2013]. Disponível em: http:// www.abep.org/criterio-brasil.

12. Haynes RB, Taylor DW, Sackett DL. Compliance in health care. Baltimore: Johns Hopkins University Press; 1981.

13. Morisky DE, Green LW, Levine DM. Concurrent and predictive validity of self-reported measure of medication adherence. Med Care. 1986;24(1):67-74.

14. World Health Organization. Collaborating Centre for Drug Statistics Methodology. Anatomical Therapeutic Chemical Classification System with Defined Daily Doses (ATC/DDD Index) [Internet]. Oslo: WHO; 2006. [acesso em 23 Jan. 2013]. Disponível em: http:// www.whocc.no/atcddd/

15. Silva AL, Ribeiro AQ, Klein CH, Acurcio FA. Utilização de medicamentos por idosos brasileiros, de acordo com a faixa etária: um inquérito postal. Cad Saúde Pública. 2012;28(6):1033-45.

16. Santos TR, Lima DM, Nakatani AYK, Pereira LV, Leal GS, Amaral RG. Consumo de medicamentos por idosos, Goiânia, Brasil. Rev Saúde Pública. 2013;47(1):94-103.

17. Wändell P, Carlsson AC, Wettermark B, Lord G, Cars T, Ljunggren G. Most common diseases diagnosed in primary care in Stockholm, Sweden, in 2011. Fam Pract. 2013;30(5):506-13.
18. Alpert JS. Polypharmacy in elderly patients: the march goes on and on [editorial]. Am J Med. 2017;130(8):875-6.

19. Pereira KG, Peres MA, Iop D, Boing AC, Boing AF, Aziz M, et al. Polifarmácia em idosos: um estudo de base populacional. Rev Bras epidemiol [Internet]. 2017 [acesso em 29 ago. 2017];20(2):335-44. Disponível em: http://www. scielo.br/scielo.php?script $=$ sci_arttext\&pid $=$ S1415790X2017000200335\&lng=en.

20. Pereira SAS. Investigação farmaco-epidemiológica em prescrições médicas da atenção básica: o caso do idoso. Academus Rev Cient Saúde [Internet]. 2016 [acesso em 23 ago 2017];1(1):1-14. Disponível em: https://smsrio.org/revista/index.php/reva/article/ view/79. [acesso em 23 ago 2017].

21. Gontijo MF, Ribeiro AQ, Klein CH, Rozenfekd $\mathrm{S}$, Acurcio FA. Uso de anti-hipertensivos e antidiabéticos por idosos: inquérito em Belo Horizonte, Minas Gerais, Brasil. Cad Saúde Pública. 2012;8(7):1337-46.

22. Natarajan N, Putnam W, Van Aarsen K, Beverley LK, Burge F. Adherence to antihypertensive medications among family practice patients with diabetes and hypertension. Can Fam Physician [Internet]. 2013 [acesso em 20 maio 2017];59(2):93-100. Disponível em: https://www.ncbi.nlm.nih.gov/pmc/articles/ PMC3576963/pdf/0590e93.pdf.

23. Carvalho ALM, Leopoldino RWD, Silva JEG, Cunha CP. Adesão ao tratamento medicamentoso em usuários cadastrados no Programa Hiperdia no município de Teresina (PI). Ciênc Saúde Coletiva. 2012;17(7):1885-92.

24. Schmitt Júnior AA, Lindner S, Helena ETS. Avaliação da adesão terapêutica em idosos atendidos na atenção Primária. Rev assoc méd Bras. 2013;59(6):614-21.

25. World Health Organization. Adherence to longterm therapies: evidence for action [Internet]. Geneva: WHO; 2003 [acesso em 20 maio 2017]. Chapter 13, Hypertension; p. 107-14. Disponível em: http://whqlibdoc.who.int/ publications/2003/9241545992.pdf.

26. Girotto E, Andrade SM, Cabrera MAS, Matsuo T. Adesão ao tratamento farmacológico e não farmacológico e fatores associados na atenção primária da hipertensão arterial. Ciênc Saúde Coletiva. 2013;18(6):1763-72.

27. Paniz VMV, Fassa AG, Facchini LA, Bertoldi AD, Piccini RX, Tomasi E, et al. Acesso a medicamentos de uso contínuo em adultos e idosos nas regiões Sul e Nordeste do Brasil. Cad Saúde Pública. 2008;24(2):267-80. 
28. Aziz MM, Calvo MCM, D’Orsi E. Medicamentos prescritos aos idosos em uma capital do Sul do Brasil e a Relação Municipal de Medicamentos. Cad Saúde Pública. 2012;28(1):52-64.

29. World Health Organization. Continuity and change: implementing the Third WHO Medicines Strategy 2008-2013 [Internet]. Geneva: WHO; 2010. [acesso em 02 jun. 2017]. Disponível em: http://www.who. int/medicines/publications/medstrategy08_13/en/.

30. Bello CB. Acesso a medicamentos: experiência da população de baixa renda na região do Butantã, São Paulo [tese]. São Paulo: Universidade de São Paulo; 2009.

31. Gregori F, Ziulkoski AL, Andrighetti LH, Lourenço ED, Perassolo MS. Acompanhamento farmacoterapêutico em pacientes dislipidêmicos de um lar de idosos da cidade de Novo Hamburgo RS. Rev Bras Geriatr Gerontol. 2013;16(1):171-80.
32. Faria MQ, Franceschini SCC, Ribeiro AQ. Estado nutricional e uso de medicamentos por idosos. Latin Am J Pharm. 2010;29(1):127-31.

33. Dellaroza MSG, Furuya RK, Cabrera MAS, Matsuo C, Yamada KN, Lílian Pacola L. Caracterização da dor crônica e métodos analgésicos utilizados por idosos da comunidade. Rev Assoc Med Bras. 2008;54(1):36-41.

34. Sociedade Brasileira de Reumatologia, Sociedade Brasileira de Medicina de Família e Comunidade. Uso de anti-inflamatórios não hormonais na dor crônica em pacientes com osteoartrite (osteoartrose). Rio de Janeiro: ANS; 2011. (Diretrizes Clínicas na Saúde Suplementar).

35. Balk RS, Torres OM, Barbosa TM, Gollino GP, Chies LFS. Avaliação das condições de armazenamento de medicamentos em domicílios do município de Uruguaiana - RS. Saúde (Santa Maria). 2015;41(2):233-40. 